RASĀYAN J. Chem.

Vol. 12 | No. 4 |2227 - 2234| October - December | 2019 ISSN: 0974-1496 | e-ISSN: 0976-0083 | CODEN: RJCABP

RJC http://www.rasayanjournal.com http://www.rasayanjournal.co.in

\title{
EFFECTS OF VINEGAR WASTE LOGGING BASED STIMULANT ON PRODUCTION OF RESIN FROM Pinus merkusii Jungh. Et De Vriese
}

\author{
A. Hadiyane", R. Dungani, T. Karliati and A. Rumidatul \\ School of Life Sciences and Technology, Gedung Labtex XI, \\ Institut Teknologi Bandung, 40132, Indonesia \\ *E-mail: anne@sith.itb.ac.id
}

\begin{abstract}
As the demand for increased pine rosin products, many attempts have been made to increase the production of pine oleoresin. Stimulant treatment is another effective treatment of increase of pine oleoresin productivity. The present study was undertaken to the effects vinegar waste logging based stimulant to increasing the pine resin production. The stimulant application was doing by dissolved 1L vinegar waste logging components with 1L oil cooking. Exactly 1cc of a mixture of such stimulants sprayed on quarre area. Pine oleoresin collection from each diameter class and various of vinegar waste logging stimulant was carried out every 3 days/period (12 days for 4 periods). Data were analyzed by one-way analysis of variance (ANOVA) and Duncan's multiple range test using SPSS software version 17. The highest resin production of $52.64 \mathrm{~g} /$ quarre/tree was recorded from the VL stimulant and the lowest resin production of $30.97 \mathrm{~g}$ /quarre/tree was found in the VF stimulant. Meanwhile, the VW of stimulant resulted in maximum pine oleoresin production (50.34 g/quarre/tree). Improvement of resin productivity by $36.70 \%$ - 199.07\% per collection. There is a correlation between type of stimulant and class diameter on productivity of pine oleoresin. The use of vinegar leaf stimulants can increase the production of resin per collection more than vinegar wood and vinegar fruit, both on the use in class diameter above $50 \mathrm{~cm}$ and below $50 \mathrm{~cm}$. Vinegar waste logging based stimulant is stimulant safe and environmentally friendly.
\end{abstract}

Keywords: Oleoresin, Tapping pine, Vinegar, Organic Stimulant, Quarre

(C) RASĀYAN. All rights reserved

\section{INTRODUCTION}

Resin from pine (Pinus merkusii) is classified as oleoresin which is the resin acid liquid in turpentine that will go out when the pine tree is injured. The production of pine oleoresin is done by tapping sapwood in order to open the resin channel. The surface on the wood will cause the oleoresin to flow, outward because inside the wood the pine oleoresin channel has a high pressure of $70 \mathrm{~atm}$. The pine oleoresin dissolves in alcohol, benzene, ether and some organic solvents, but does not dissolve in water. ${ }^{1}$

Pine oleoresin is a hydrocarbon secretion formed in special resin canals of many plants, especially coniferous trees, it is exuded in soft drops from wounds, hardening into solid masses in the air. ${ }^{2}$ It consisting of turpentine (monoterpene, $\mathrm{C}_{10}$, and sesquiterpene, $\mathrm{C}_{15}$ ) and resin (diterpene, $\mathrm{C}_{20}$ ) fractions. Tapping pine trees to obtain terpene biomass is an activity well suited to countries with a standing resource of pines, leading to many economic and social benefits such as Indonesia. Pine oleoresin processed into rosin and turpentine products. The pine rosins used on many industrial applications including synthetic rubber, coatings, paper sizing, polymerization emulsifiers, adhesive tackifiers, printing ink resins, and waterproofing material. ${ }^{3}$ Meanwhile, The pine turpentine has been traditionally employed as a solvent or cleaning agent for paints and varnishes or in the pharmaceutical industry. ${ }^{4}$

As the demand for increased pine rosin products, many attempts have been made to increase the production of pine oleoresin. Stimulant treatment is another effective treatment of increase of pine oleoresin productivity. In pine-tapping, the addition of the sulfuric acid substance is intended to reduce freezing or draining the resin out due to stem injuries. ${ }^{5}$

Rasayan J. Chem., 12(4), 2227-2234(2019)

http://dx.doi.org/10.31788/RJC.2019.1245199

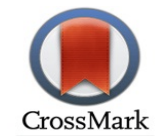


RASĀYAN J. Chem.

Vol. 12 | No. 4 |2227 - 2234| October - December | 2019

To enhance the productivity of pine resin, the stimulant can be used. The use of stimulants in pine-tapping initially used sulfuric acid $\left(\mathrm{H}_{2} \mathrm{SO}_{4}\right)$ substances with concentrations of $40 \%$ or $60 \%{ }^{6}$ and up to now sulfuric acid-based stimulants are still used in Indonesia. McReynolds and Kossuth ${ }^{7}$ investigated the application of sulfuric acid as stimulant to increase productivity of oleoresin under riil method tapping. They showed that productivity pine oleoresin can increase until 56-111\%. They considered that these acids include stronger oxidizing agents that can damage wood tissue and open the resin channel.

Meanwhile, wood vinegar is a product by the processing of high-temperature carbonization without oxygen. This wood vinegar contains several organic compounds (carbonyl, various kinds of phenol, and alcohol). Product vinegar also using in pesticide application as wood preservative (fungicide, and insecticide). ${ }^{8}$ Several studies have been by researcher about wood vinegar as preservatives, such as in wood vinegar from Toona sinensis ${ }^{9}$ and from oil palm trunk. ${ }^{10}$ Results show that wood vinegar might be responsible for the termiticidal activity. Furthermore, many attempts have been made to increase resin production in sap-producing tree species by wood vinegar as organic stimulants. ${ }^{11}$ Wood vinegar from galangal (Alpinia galangal) can increase sap production for latex jelutong (Dyera $\mathrm{sp}){ }^{12}$

Based on this, wood vinegar as a stimulant material has the opportunity to be developed. The advantages of wood vinegar stimulants are that they are easy to make/produce, inexpensive, safe to use, environmentally friendly and have added value because they utilize waste. In this study the wood vinegar used came from Based on this, wood vinegar as a stimulant material has the opportunity to be developed. The advantages of wood vinegar stimulants are that they are easy to make/produce, inexpensive, safe to use, environmentally friendly and have added value because they utilize waste. In this study the wood vinegar used came from waste logging of $P$. merkusii, such as fruit, leaf and chips to increasing the pine resin production.

\section{EXPERIMENTAL}

Plant Material and Resin Tapping Operation

Resin tapping was done by the "quarre" system in 28 years old slash pine (Pinus merkusii Jungh. Et De Vriese) trees, grown in Bosscha Observatory area, in West Bandung District, Indonesia (the elevation between 1,000-1,500 m.a.s.1.). The P. merkusii stands used in the study had not been tapped for resin prior to the experiments. A total of 100 sample trees were marked for resin collection. The sample trees were distributed equally for each diameter class. Based on various tree diameters found in study site, all trees were classified into two classes of diameter (30-40 cm and 40-50 cm, respectively).

\section{Vinegar Waste Logging Based Stimulant}

The raw materials of vinegar waste logging based stimulants $\mathrm{A}, \mathrm{B}$, and $\mathrm{C}$ were fruit, leaf and chips of $P$. merkusii, respectively. Sample B was prepared by a block-type kiln for carbonization of leaf briquettes prepared by pressurized molding. Fruit as raw material for samples A and chips branch for samples $\mathrm{C}$ were prepared using a modification charcoal kiln (Fig.-1).

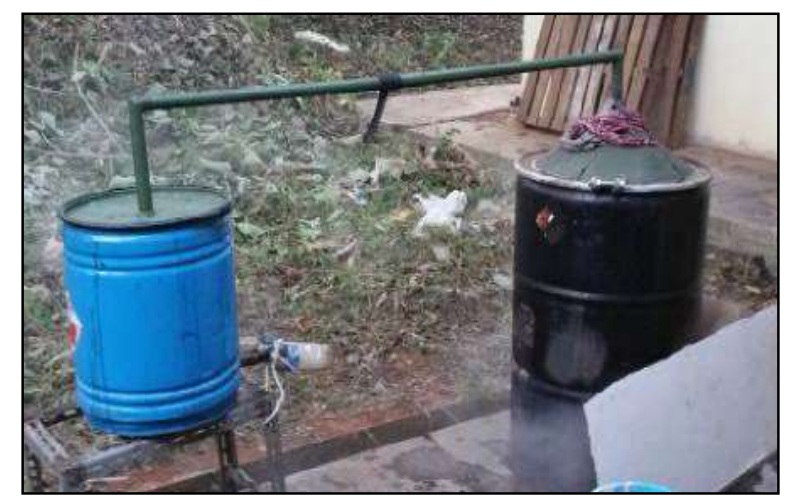

Fig.-1: The Modification of Charcoal Kiln

Each of the samples arranged in the 100-liter drum kiln, close before burning. The samples processed to vinegar waste logging is produced by carbonization ranges between 80 and $180^{\circ} \mathrm{Cuntil}$ approximately 2 to 
RASĀYAN J. Chem.

Vol. 12 | No. 4 |2227 - 2234| October - December | 2019

3 hour. Vinegar waste logging collected with containers fastened underneath one to two holes, approximately $2 \mathrm{~cm} \mathrm{(3/4} \mathrm{in.)} \mathrm{wide.} \mathrm{The} \mathrm{composition} \mathrm{of} \mathrm{vinegar} \mathrm{waste} \mathrm{logging} \mathrm{stimulant} \mathrm{used} \mathrm{is} \mathrm{made} \mathrm{with}$ a ratio of 1: 1 (vinegar waste logging: cooking oil).

\section{Identification of Vinegar Waste Logging Components}

The identification of each component was done by gas chromatography-mass spectrometry (GC-MS) (HP, 6890-GC/5973- MSD). The GC column was a $30 \mathrm{~m} \times 0.25 \mathrm{~mm}$ glass capillary. A split less injection of 1/A was used. The carrier gas was helium (flow rate $1.0 \mathrm{ml} / \mathrm{min}$ ). MS was EI mode $(70 \mathrm{eV})$. The peak was confirmed by comparison with a standard in the NIST library data.

\section{Stimulant Application}

The process of quarre method is done with the first step was the stem of pine that will be tapped cleaned of bark, then wounded with tools "kedukul", with the size of the quarre of $5 \mathrm{~cm}$ width, height $15 \mathrm{~cm}$ and thickness of $\pm 2 \mathrm{~cm}$. The direction of quare was vertical so that the resin can flow into plastic glass (Fig.2). The stimulant application was doing by dissolved $1 \mathrm{~L}$ vinegar waste logging components with $1 \mathrm{~L}$ oil cooking. Exactly 1cc of a mixture of such stimulants sprayed on quarre area. Pine oleoresin collection from each diameter class and various of vinegar waste logging stimulant was carried out every 3 days/period (12 days for 4 periods).

\section{Statistical Analysis}

A one-way analysis of variance (ANOVA) and Duncan's multiple range test was used to analyze the data. All statistical tests were performed using SPSS at a 95\% confidence level.

\section{Main Components of Waste Logging Vinegar}

\section{RESULTS AND DISCUSSION}

Acetic acid is the largest component of the acid portion and is the largest of all the components of waste logging vinegar. Table-1 showed that acid accounts for more than $50 \%$ of waste logging vinegar.

Table-1: Chemical Composition of Vinegar Waste Logging Based Stimulant by GC-MS Analysis

\begin{tabular}{|c|c|c|c|}
\hline Names of components & $\begin{array}{l}\text { Retention } \\
\text { time (mim) }\end{array}$ & $\begin{array}{l}\text { Molecular } \\
\text { formula }\end{array}$ & $\begin{array}{c}\text { Peak } \\
\text { area }(\%)\end{array}$ \\
\hline \multicolumn{4}{|l|}{ A. Vinegar fruit (VF) } \\
\hline - Carbamic acid, mono ammonium salt (CAS) ammonium carbamate & 3.541 & $\mathrm{CH}_{3} \mathrm{NO}_{2}$ & 44.00 \\
\hline - Bicyclo [2.2.1] heptane,-5-(Ethyl-1-amine) & 3.950 & $\mathrm{C}_{9} \mathrm{H}_{17} \mathrm{~N}$ & 43.95 \\
\hline - Acetic acid (CAS) Ethylic acid & 5.545 & $\mathrm{C}_{2} \mathrm{H}_{4} \mathrm{O}_{2}$ & 43.00 \\
\hline - 2(3H)-Furanone, dihydro- (CAS) butyrol actone & 11.434 & $\mathrm{C}_{4} \mathrm{H}_{6} \mathrm{O}_{2}$ & 42.00 \\
\hline - 2,5-Dimethyl Cyclopentanone B & 13.017 & $\mathrm{C}_{7} \mathrm{H}_{12} \mathrm{O}$ & 42.00 \\
\hline - Phenol, 4-methoxy- (CAS) Hqmme & 13.528 & $\mathrm{C}_{7} \mathrm{H}_{8} \mathrm{O}_{2}$ & 80.95 \\
\hline - Pentanal (CAS) n-pentanal & 13.916 & $\mathrm{C}_{5} \mathrm{H}_{10} \mathrm{O}$ & 44.00 \\
\hline - 2-Methoxy-4-methylphenol & 14.683 & $\mathrm{C}_{8} \mathrm{H}_{10} \mathrm{O}_{2}$ & 138.05 \\
\hline - Acetamide, N-(3-hydroxyphenyl)- (CAS) Nebs & 17.700 & $\mathrm{C}_{8} \mathrm{H}_{9} \mathrm{NO}_{2}$ & 43.00 \\
\hline - Acetic acid, phenyl ester (CAS) Phenyl acetate & 17.991 & $\mathrm{C}_{8} \mathrm{H}_{8} \mathrm{O}_{2}$ & 43.05 \\
\hline - Ethanimidicacid, N-hydroxy-, ethyl ester & 18.350 & $\mathrm{C}_{4} \mathrm{H}_{9} \mathrm{NO}_{2}$ & 43.05 \\
\hline \multicolumn{4}{|l|}{ B. Vinegar wood part (VW) } \\
\hline - Carbamic acid, mono ammonium salt (CAS) ammonium carbamate & 3.576 & $\mathrm{CH}_{3} \mathrm{NO}_{2}$ & 44.00 \\
\hline $\begin{array}{c}\text { - 1,4-Benzenedicarboxylic acid, [4-(methoxy carbonyl)phenyl]methyl } \\
\text { ester }\end{array}$ & 3.894 & $\mathrm{C}_{18} \mathrm{H}_{16} \mathrm{O}_{6}$ & 43.95 \\
\hline - Propanoic acid, 2-oxo- (CAS) pyruvic acid & 4.498 & $\mathrm{C}_{3} \mathrm{H}_{4} \mathrm{O}_{3}$ & 43.00 \\
\hline - Acetic acid (CAS) ethylic acid & 7.383 & $\mathrm{C}_{2} \mathrm{H}_{4} \mathrm{O}_{2}$ & 45.00 \\
\hline - 2-Propanone, 1-hydroxy- (CAS) acetol & 7.650 & $\mathrm{C}_{3} \mathrm{H}_{6} \mathrm{O}_{2}$ & 43.05 \\
\hline - 2(3H)-Furanone, dihydro-(CAS) butyrol actone & 11.409 & $\mathrm{C}_{4} \mathrm{H}_{6} \mathrm{O}_{2}$ & 42.00 \\
\hline - 2,5-Dimethyl cyclopentanone B & 12.992 & $\mathrm{C}_{7} \mathrm{H}_{12} \mathrm{O}$ & 42.10 \\
\hline - Phenol, 2-methoxy- (CAS) Guaiacol & 13.514 & $\mathrm{C}_{7} \mathrm{H}_{8} \mathrm{O}_{2}$ & 81.10 \\
\hline
\end{tabular}


RASĀYAN J. Chem.

Vol. 12 | No. 4 | 2227 - 2234| October - December | 2019

\begin{tabular}{|c|c|c|c|}
\hline - Butane, 2-methyl- (CAS) Isopentane & 13.906 & $\mathrm{C}_{5} \mathrm{H}_{12}$ & 44.00 \\
\hline - 2-Methoxy-4-methyl phenol & 14.697 & $\mathrm{C}_{8} \mathrm{H}_{10} \mathrm{O}_{2}$ & 138.00 \\
\hline - 2-Propenoic acid, 2-methyl-, 2-hydroxy propyl ester & 15.209 & $\mathrm{C}_{7} \mathrm{H}_{12} \mathrm{O}_{3}$ & 69.00 \\
\hline - Ethanone,1-[5-(1-Hydroxy ethylidene)-1,3-Cyclo pentadien-1-Y & 17.700 & $\mathrm{C}_{9} \mathrm{H}_{10} \mathrm{O}_{2}$ & 43.05 \\
\hline - Acetic acid, phenyl ester (CAS) Phenyl acetate & 17.985 & $\mathrm{C}_{8} \mathrm{H}_{8} \mathrm{O}_{2}$ & 43.00 \\
\hline - Hydrazine, 1,1-dimethyl- (CAS) N,N-Dimethyl hydrazine & 18.476 & $\mathrm{C}_{2} \mathrm{H}_{8} \mathrm{~N}_{2}$ & 42.00 \\
\hline $\begin{array}{l}\text { - Benzene acetic acid, 4-hydroxy-3-methoxy- (CAS) Homo vanillic } \\
\text { acid }\end{array}$ & 18.974 & $\mathrm{C}_{9} \mathrm{H}_{10} \mathrm{O}_{4}$ & 137.00 \\
\hline \multicolumn{4}{|l|}{ C. Vinegar leaf (VL) } \\
\hline - Bicyclo [2.2.1] Heptane,-5-(Ethyl-1-Amine) & 3.740 & $\mathrm{C}_{9} \mathrm{H}_{17} \mathrm{~N}$ & 43.90 \\
\hline - Acetic acid (CAS) Ethylic acid & 3.958 & $\mathrm{C}_{2} \mathrm{H}_{4} \mathrm{O}_{2}$ & 42.95 \\
\hline - 1,1,4,4-Tetra deuterioterta methylene diamine & 4.429 & $\mathrm{C}_{4} \mathrm{H}_{8} \mathrm{D}_{4} \mathrm{~N}_{2}$ & 43.05 \\
\hline - (2S,3S)-2,3-epoxybutanol & 7.258 & $\mathrm{C}_{4} \mathrm{H}_{8} \mathrm{O}_{2}$ & 43.00 \\
\hline
\end{tabular}

The gas chromatography mass spectral analysis of the vinegar fruit (VF) revealed the presence of four main compounds. The major compound present in the VF was 1,2-diethyldiborane, acetic acid, ethylic acid and bicyclo heptane, -5-(ethyl-1-amine) was found to be the next compound present at higher concentration with peak area of about $5.67 \%$ at 38.82 retention time. The major compound in the vinegar leaf (VL) presence of Acetic acid (CAS) Ethylic acid, 1,1,4,4 tetra deuterioterta methylene diamine and (2S,3S)-2,3-epoxy butanol. Meanwhile, vinegar wood part (VW) revealed the presence of four main compounds. 1,4 benzene dicarboxylic acid, [4-(methoxy carbonyl) phenyl] methyl methylest, hydrazine, 1,1-dimethyl-(CAS) N,N-dimethyl hydrazine, propanoic acid, 2-oxo- (CAS) pyruvic acid and 2-hexyl acetate were the major compound with peak area of about $4.83 \%$ at 31.17 retention time.

\section{Productivity of Pine Oleoresin}

The results showed significant differences in pine oleoresin production between the three stimulant. The highest resin production of $52.64 \mathrm{~g} /$ quarre/tree was recorded from the VL stimulant and the lowest resin production of $30.97 \mathrm{~g} /$ quarre/tree was found in the VF stimulant. Meanwhile, the VW of stimulant resulted in maximum pine oleoresin production (50.34 g/quarre/tree), while the control produces 16.06 $\mathrm{g} /$ quarre/tree/collection or increase the resin production by $36.70 \%-199.07 \%$ per collection. Mean pine oleoresin production by various stimulant under diameter classes were displayed in Table- 2 .

Table-2: The Yield of Pine Oleoresin Based on Stimulants Types, class of Diameter and Period of Collection ( $\mathrm{g} /$ quarre/collection)

\begin{tabular}{|c|c|c|c|c|c|}
\hline \multirow{2}{*}{$\begin{array}{c}\text { Class } \\
\text { diameter } \\
(\mathrm{cm})\end{array}$} & \multirow{2}{*}{$\begin{array}{l}\text { Period of } \\
\text { collection }\end{array}$} & \multicolumn{3}{|c|}{ Type of stimulant } & \multirow{2}{*}{ Control } \\
\hline & & VF & VW & VL & \\
\hline & I & 2692 & 3366 & 3738 & 350 \\
\hline & II & 28.24 & 56.19 & 78.01 & 26.21 \\
\hline \multirow[t]{2}{*}{$30-40$} & III & 43.23 & 65.91 & 73.03 & 17.57 \\
\hline & IV & 25.50 & 45.60 & 22.15 & 16.98 \\
\hline \multicolumn{2}{|c|}{ Average } & 30.97 & 50.34 & 52.64 & 16.06 \\
\hline \multicolumn{2}{|c|}{ Improvement (\%) } & 90.28 & 213.45 & 227.77 & - \\
\hline & I & 71.52 & 38.30 & 80.27 & 20.01 \\
\hline & II & 63.63 & 85.28 & 93.69 & 27.81 \\
\hline \multirow[t]{2}{*}{$40-50$} & III & 65.41 & 130.10 & 138.39 & 21.42 \\
\hline & IV & 63.55 & 95.11 & 101.11 & 24.25 \\
\hline \multirow{2}{*}{\multicolumn{2}{|c|}{$\begin{array}{c}\text { Average } \\
\text { Improvement (\%) }\end{array}$}} & 66.03 & 86.45 & 103.36 & 24.12 \\
\hline & & 173.75 & 258.42 & 328.52 & - \\
\hline
\end{tabular}

Remarks: The number of sample 80 trees and the time of collections were 4 periods $=48$ days

Based on Table- 2 it is shown that the variation of pine oleoresin obtained is influenced by the treatment of the stimulant and the diameter classes in each collection resin period. In each collection resin period, the pine oleoresin generated by each type of stimulant tends to increase when compared to the control. The 
RASĀYAN J. Chem.

Vol. 12 | No. 4 |2227 - 2234| October - December | 2019

production of pine resin obtained at the class diameter above $40 \mathrm{~cm}$, where the range of resin production obtained due to the stimulation ranges from 66.03-103.36 gram /quarre /collection or can increase the production of resin per collection by $173.75 \%-328.52 \%$ compared with the control.

The result of the pine oleoresin obtained at each treatment according to Table-1 then analyzed to determine the extent of the influence of the type of stimulant treatment and class diameter and its interaction with the pine oleoresin production. The result of variance analysis of the effect of each treatment on the production of resin produced can be seen in Table-3.

Table-3: Anova of The Effect of Using Stimulants toward Resin Pine Yield Based on the Treatments

\begin{tabular}{c|c|c|c|c|c}
\hline Source of variant & $\begin{array}{c}\text { Degree of } \\
\text { freedom }\end{array}$ & sum of square & Mean square & F-calculated & Prob \\
\hline Stimulant (S) & 3 & 213171.837 & 71057.279 & 90.22 & $0.0001^{*}$ \\
\hline Class diameter (D) & 1 & 8715.316 & 8715.322 & 11.07 & $0.0010^{*}$ \\
\hline S x D & 3 & 14755.838 & 4918.613 & 6.24 & $0.0004^{*}$ \\
\hline Period & 3 & 165853.663 & 55284.554 & 70.19 & $0.0001^{*}$ \\
\hline Error & 309 & 243381.237 & 787.641 & & \\
\hline Total & 319 & 645877.887 & - & & \\
\hline
\end{tabular}

Remarks: * = significantly different

Based on Table- 3 it can be seen that the type of stimulant used in pine tapping, diameter class, stimulant interaction and diameter class, as well as pine oleoresin collection period, significantly affect the production of resin produced. LSD test was used to determine whether addition of stimulant would show any significant effects on the production of pine oleoresin is presented in Table 4 . The productivity of resin is influenced by stimulant factors. ${ }^{13-15}$ Addition of stimulants is useful as an ethylene stimulant in plants that can increase osmotic pressure and turgor pressure that causes the resin flow to accelerate and last longer. A strong acid-based stimulant, VL causes the production of resin to increase per collection as it can prolong the time of drainage by reducing the turgor pressure (turgensis) in epithelial cells and preventing the crystallization of the resin and the formation of tylosoid ${ }^{15,16}$ Furthermore, the mechanism of giving a strong acid-based stimulant will give a heat effect on the resin so that the resin is longer in the liquid state thus easily flowing out of the resin channel and affect the turgor pressure of the cell wall so that the resin quickly out and the lymph can open in a relatively long time. ${ }^{17}$

Table-4: LSD Test on the Effect of Using Stimulants toward Oleoresin Pine Yield Based on the Treatments

\begin{tabular}{c|c|c}
\hline No & Treatment & Average of oleoresin pine yield \\
\hline 1. & Stimulant (S): & $48.50 \mathrm{a}$ \\
\hline & vinegar fruit (VF) & $68.39 \mathrm{~b}$ \\
\hline & vinegar wood part (VW) & $78.00 \mathrm{~b}$ \\
\hline & vinegar leaf (VL) & $20.09 \mathrm{c}$ \\
\hline 2. & Control (C) & $37.50 \mathrm{a}$ \\
\hline & Class diameter (D) & $69.99 \mathrm{~b}$ \\
\hline & D1 & $66.03 \mathrm{a}$ \\
\hline 3. & D2 & $30.97 \mathrm{~b}$ \\
\hline & Interaction S*D & $86.45 \mathrm{c}$ \\
\hline & VF*D2 & $50.34 \mathrm{c}$ \\
\hline & VF*D1 & $103.36 \mathrm{~cd}$ \\
\hline & VW*D2 & $52.64 \mathrm{cde}$ \\
\hline & VW*D1 & $24.12 \mathrm{cde}$ \\
\hline & VL*D2 & $16.06 \mathrm{e}$ \\
\hline
\end{tabular}

Remarks: ${ }^{*}=$ significantly different $5 \%$, number that followed different characters means significantly different 
RASĀYAN J. Chem.

Vol. 12 | No. 4 |2227 - 2234| October - December | 2019

The addition of waste logging-based vinegar stimulants can increase the production of pine oleoresin due to acetic acid $\left(\mathrm{C}_{2} \mathrm{H}_{4} \mathrm{O}_{2}\right)$ content that can contribute to expediting the resin out due to the heat effect generated from its acid content, although not extreme as it is caused by strong acids. Cooking oil in this study serves as a heat transfer medium that is expected to transfer heat longer than sunlight on wound taps. In addition to acetic acid, other waste logging based vinegar content such as methanol, phenol, carbonyl are thought to stimulate epithelium in plants to increase osmotic pressure and turgor pressure which causes the resin flow to accelerate and last longer. According to Hillis ${ }^{18}$, the entry of water into the epithelial lumen of the epithelial cells will cause the enlarged epithelial cells and will subsequently suppress the resin inside the resin channel so that the resin is destroyed and pushed out, after which epithelial cells will produce resin substances back to fill the resin channel.

The diameter of the tree affects pine resin production, whereby the larger the diameter, the resulting resin will increase because the pine resin generated in large diameter gives high yield and the resin channel present in the tree trunk more. ${ }^{14}$ The diameter effect on pine oleoresin production is related to the growth of tree diameter, resulting in a greater volume of sapwood. The greater the volume of sapwood, the channel resin contained in pine trees will be more and more and the production of resin will increase. ${ }^{19}$ The amount of sap produced by one tree is determined by its age and diameter. The addition of age and diameter will lead to increased resin productivity. ${ }^{20}$

Coppen and Hone ${ }^{21}$ considered that the increase in diameter is believed to increase the volume of sapwood. These results suggested that the sapwood composes of cells that contain physiologically active photosynthesis results, where resin is produced and stored in tree's phloem and xylem ${ }^{22,23}$. Hadiyane et. $a l^{24}$ studies of correlation between class diameter with productivity of pine oleoresin. They reported that the average pine oleoresin production of diameter class $38-40 \mathrm{~cm}$ is higher than the averages for diameter class $30-32,32-34,34-36$ and $36-38 \mathrm{~cm}$. They also observed that the greater the diameter of the tree tapped and the bigger the proportion of sapwood, the greater the resin yields.

\section{Structural Damage During Tapping}

The part of the stem of pine have been tapping reacted to the action of elements stimulant, and there were notable differences in the structural changes of these two type of stimulant (vinegar and $\mathrm{H}_{2} \mathrm{SO}_{4}$ ) after one month of tapping (Fig.-2b). The color of the nodules formed on stem tapped pine trees was common to find blackish or chocolate-like discoloration on the stem. This signifies that the nodules and wood discoloration beneath it are good symptoms of infection. According to Gezahgne et al. ${ }^{25}$, nodule occurs on a wide variety of plants and it can be caused by microbe activity and man activity such as stimulant. A study by $\mathrm{Li}^{26}$ shows that the influence of using stimulants on tree growth is often due to the damage of cambium.
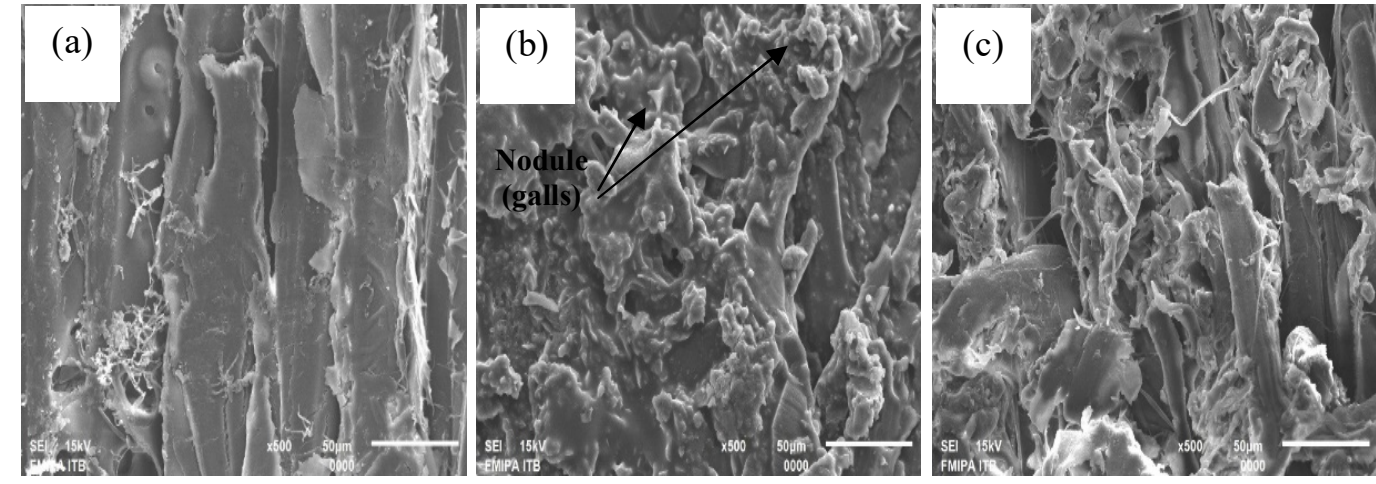

Fig.-2: Scanning lectron Microscopy (SEM) of Pine Tapped. (a) Without Stimulant; (b) After Treatment of Sulfuric Acid Stimulant; (c) After Treatment of Vinegar Stimulant

As can be observed in Fig.-2a, there are gum cavity arises schizogenous without damage in the axial parenchyma of sapwood upon tapping. Furthermore, compared to the vinegar stimulant shown in Fig.-2c, showed the little presence of damaged part of the stem after treatment. The gum duct was formed in all 
the experimental trees through the application of vinegar stimulant which is non-toxic, environmentally friendly, and inexpensive. However, it seems that secretory tissue occurs normally in these trees but in response to external stimulant i.e. (biotic and abiotic) tissue (injuries, pathogen, exogenous growth substances) affect formation of gum duct.

\section{CONCLUSION}

The addition of stimulants is used to increase and lengthen the resin residue so that the pine oleoresin obtained per more collections. The use of vinegar leaf stimulants can increase the production of resin per collection more than vinegar wood and vinegar fruit, both on the use in class diameter above $50 \mathrm{~cm}$ and below $50 \mathrm{~cm}$. Acetic acid (CAS) ethylic acid group exhibited higher stimulant activity, these can contribute to expediting the resin out due to the heat effect generated from its acid content, although not extreme as it is caused by strong acids. The loss of middle lamellar cohesiveness and the breakdown of the primary cell walls in the phloem tissue in and around gum pockets due to stimulant sulfuric acid treatment. vinegar waste logging based stimulant has an advantage in times of green product, where the product of the forest produced must be safe and environmentally friendly.

\section{ACKNOWLEDGMENT}

The author would like to thank Research of Higher Education, Ministry of Research Technology and the Higher Education Republic of Indonesia, for providing Research Grant No.845/AL-J/DIPA/PN/SPK/2017 for this research.

\section{REFERENCES}

1. K.C.S, Rodrigues, M.A. Apel, A.T. Henriques, and A.G. Fett-Neto, Biomass and Bioenergy, 35, 4442(2011), DOI: 10.1016/j.biombioe.2011.08.021

2. J. Bohlmann, C.L. Keeling, Plant J., 54(4), 656(2008), DOI: 10.1111/j.1365-313X.2008.03449.x

3. J. Stubbs, D.R. Roberts, and K.W. Outcalt. Chemical stimulation of lightwood in southern pines. Asheville, North Carolina: United States Department of Agriculture, Forest Service, Southeastern Forest Experiment Station, p. 51(1984)

4. FAO. FRA 2000 non-wood forest products study for Mexico, Cuba and south America. Rome: Forestry Department, Food and Agriculture Organization of the United Nations, p. 72(1999)

5. P. Bhardwaj, K.R. Sharma, K.R., and P.K. Khosla, Int. J. Pharm. Sci. Res., 8(5), 2213(2017), DOI: 10.13040/IJPSR.0975-8232.8(5).2213-17.

6. A. Sukarno, E.B. Hardiyanto, S.N. Marsoem and M. Na'iem, Jurnal Pembangunan Alam Lestari, 4, 38(2013).

7. R.D. McReynolds and S.V. Kossuth, South J. Appl. For., 8(3), 168(1984), DOI: 10.1016/j.biombioe.2011.08.021

8. R.T. Toledo, Wood Smoke Components and Functional Properties. In: D.E. Kramer and L. Brown (eds.), International Smoked Seafood Conference Proceedings. Alaska Sea Grant College Program, Fairbanks, pp. 55-61, DOI:10.4027/isscp.2008.12

9. M. Adfa, A.J. Kusnanda, W.D. Saputra, C. Banon, M. Efdi, and M. Koketsu, Rasayan J. of Chem., 10(4), 1088(2017), DOI: 10.7324/RJC.2017.1041866

10. H.A. Oramahi, T. Yoshimura, F. Diba, D. Setyawati, and Nurhaida, J. of Wood Sci.,64, 311(2018), DOI: $10.1007 / \mathrm{s} 10086-018-1703-2$

11. D.M. Martin, J. Gershenzonand, J. Bohlmann. Plant Physiology,132, 1586(2003).

12. Sukadaryati, Dulsalam and Yuniawati. Journal of Tropical Forest Science, 28(4), 527(2016)

13. K.C.S. Rodrigues, and A.G. Fett-Neto. Ind Crops Prod.,30(2), 316(2009), DOI: 10.1186/1753-65615-S7-P100

14. K.C.S. Rodrigues, P.C.N. Azevedo, L.E. Sobreiro, P. Pelissari, A.G. Fett- Neto, Ind Crops Prod.,27(3), 322(2008), DOI: 10.1016/j.indcrop.2009.06.004

15. S. Taft, A. Najar, J. Godbout, J. Bousquet, and N. Erbilqin, Front Plant Sci,,6(342), 1(2015), DOI: $10.3389 /$ fpls. 2015.00342

16. J. Zhao, L.C. Davis, and R. Verpoorte, Biotechnol Adv.,23(4), 283(2005), DOI: 10.1016/j.biotechadv.2005.01.003

17. K.R. Sharma, and C. Lekha, Adv. For. Lett., 2, 51(2013). 
RASĀYAN J. Chem.

Vol. 12 | No. 4 |2227 - 2234| October - December | 2019

18. W.E. Hillis, Heartwood and Tree Exudate. Springer Verlag. Berlin Heidelberg, New York, London (1987)

19. R.G. Latta, Y.B. Linhart, M.A. Snyder, and L. Lundquist, Biochem. Syst. Ecol., 31(5), 451(2003), DOI: $10.1007 / \mathrm{s} 00049-005-0331-7$

20. J.N.R. Samanta, R. Saravanan, N.A. Gajbhiye and K. Mandal, J. Trop. For. Sci., 24, 538(2012)

21. J. J.W. Coppen, and G.A. Hone, Gum Naval Stores: Turpentine and Rosin from Pine Resin. 2nd Edn., Natural Resources Institute, Food and Agriculture Organization, Rome, Italy, p. 62(1995)

22. C.A. Gallis, A. Papajannopoulos, and E. Papadopoulou, Forest Chemical Review.,116(5), 4(2006), DOI: $10.13140 / 2.1 .2924 .608$

23. V.R.P. Franceschi, E. Krokene, E. Christiansen and T. Krekling, New Phytol.,167, 353(2005), DOI: $10.1111 / j .1469-8137.2005 .01436 . x$

24. A. Hadiyane, E. Sulistyawati, W.P. Asharina and R. Dungani., 2015. Asian J. Plant Sci., 14(2), 89(2015), DOI: 10.3923 /ajps.2015.89.93

25. A. Gezahgne, A. Yirgu, and H. Kassa, Ethiop. J. Agric. Sci.,27(1), 89(2017).

26. Z. Li, 1991. Yunnan For. Sci. Technol.,3, 78(1991), DOI:10.1016/j.jfe.2005.10.001

[RJC-5199/2019] 